\title{
Criminal justice in Orlando
}

\author{
By Eleanor Farrall \\ Reference Librarian \\ Arizona State University
}

\section{The 1986 meeting of the Academy of Criminal Justice}

\section{Sciences.}

$\mathbf{R}$ ney's entertainment meccas jammed all six lanes of International Drive, the roadway abutting the Orlando Marriott. Inside the hotel activity was almost as frenzied. The 1986 annual meeting of the Academy of Criminal Justice Sciences (ACJS) was in session. Program choices included five plenary sessions and 206 panels of three or four papers each to be presented from eight a.m. on Monday, March 17, to noon on Friday, March 21. The theme for all this activity was "Twenty Years of Challenging Crime in a Free Society," a title derived from the 1967 report of the President's Commission on Law Enforcement and Administration of Justice.

The 1,600 member Academy, founded in 1963, promotes the professional advancement of the criminal justice system through education and research. Its membership roster includes teachers, administrators, researchers, students, and practitioners. Themes of its presented papers are catholic, ranging from international terrorism to internships; correctional dynamics to privatization of services; victimless crime to probation; apartheid to domestic violence, and dozens of areas in between.

ACJS annual meetings afford members opportunities to present papers, share research, bridge the gaps between academicians and practitioners, and, through its plenary sessions, hear issues discussed by the acknowledged experts in the field. Seats at any of the ninety-minute panels may be at a premium, or the panel may outnumber the audience. The time of day, the day of the presentation, the reputation and influence of panel participants, the speaker's support network at the conference all are variables affecting attendance.

As the Justice Studies Subject Specialist at Arizona State University, I was attending my fourth ACJS conference, this time with partial funding from ACRL's Professional Liaison Committee. As chair of the Library Committee of ACJS I was presenting the results of a survey to determine the type and frequency of library usage by criminal justice academicians and their perceptions of the role of the library and librarian in the education process. As a conferee I heard discussions on terrorism, computer-aided instruction, experiential education, curricula comparisons, education vs. training, ombudsman applications, women in the criminal justice field, and the oft mentioned contributions of the defunct Law Enforcement Education Program to criminal justice education.

The standing Library Committee within the ACJS organizational structure is in its fourth year, currently composed of its original three members. Programs are presented at each annual meeting. In various cities a few local librarians have participated in the panels. Promotion of these sessions within the parent organization has met with limited success. A demonstration of online computer searching with the carrot of free searches has been the most successful program to date.

The movement of academic librarians into nonlibrary associations seems to be gaining momentum, spurred on no doubt by such factors as the success of public librarians' political gains within 
state leagues of cities and towns, the interorganizational awareness of medical, business and legal librarians, specialization within bibliographer and reference assignments, and the promotion of professional association liaison activities by ACRL.

Librarians wishing to promote professional liaison must be enthusiastic and persistent. Adding active participation in another professional association to participation in local, regional, state or national library associations will require additional funding and leave time. Both personal dedication and institutional support must be present.

Promoting a library committee within an association could prove self-defeating if only librarians are on the committee. Librarians talking to fellow librarians is a fine idea for collegial networking and very useful, but it does not promote the visibility of librarians in the organization or encourage other professional contacts. Far more effective, it seems to me, would be to inflitrate existing committees and integrate one's ideas into their functions. Developing a supporting network within the organization is imperative if activities are to be productive. Utilizing well-known members at sessions sponsored by librarians, or serving on panels set up by association members will prove effective. All such activities will open channels for marketing library functions.

The librarian who accepts the challenge of professional liaison may often feel like the circus performer astride two horses. Keeping aboard both may not always be easy; the temptation exists to bail off both or step back astride one. The determined performer will master both. The librarian who participates in both library and other professional associations has the opportunity to develop perspective, objectivity and an understanding of the library profession in its relationship to other fields.

\title{
Chapter visits
}

\section{The ACRL President-Elect reports on two recent chapter}

\author{
meetings.
}

\begin{abstract}
M issouri, April 25. ACRL's Missouri Chapter asked me to give the keynote address at their Spring Conference at Maryville. The conference theme was "Library Automation: Realities and Rewards." It was appropriately held at Northwest Missouri State University, which has a beautiful new electronic library utilizing a number of the latest library technologies, including the LS 2000 system.

The conference included sessions on indexing for the online catalog, on system planning, on electronic mail, on barcoding, user training, and patron access and identification. The 70 participants were provided with very practical and muchneeded information on planning and implementing a library automation system, including positive
\end{abstract}

and negative aspects.

It was indeed a privilege to visit a new library facility built for technology and to experience various automated library services, including a video teaching system. Nancy Hanks, the director of the B.D. Owens Library, can be proud of her and her staff's accomplishment. I also appreciated the fine Missouri hospitality, especially the dinner with Madonna and Tom Kennedy at the Apple Tree.

Montana, May 1-3. I arrived at Kalispell on an absolutely beautiful, clear and sunny afternoon and received a warm welcome from members of the Montana Library Association who were meeting jointly with ACRL's Montana Chapter. My first view of the Glacier Park mountains was 